Isabel Miguel, Joaquim P. Valentim \& Felice Carugati

\title{
Social representations of the development of intelligence, parental values and parenting styles: A theoretical model for analysis
}

\section{Article (Accepted version) (Refereed)}

\section{Original citation:}

Miguel, I., Valentim, J.P., \& Crarugati, F. (2013). Social representations of the development of intelligence, parental values and parenting styles: A theoretical model for analysis. European Journal of Psychology of Education, 28(4), 1163-1180.

doi: $10.1007 / \mathrm{s} 10212-012-0160-3$

This document is the author's final manuscript accepted version of the journal article, incorporating any revisions agreed during the peer review process. Some differences between this version and the published version may yet remain.

The final publication is available at: link.springer.com/article/10.1007\%2Fs10212-012-0160-3 


\section{ABSTRACT}

Within the theoretical framework of social representations theory, a substantial body of literature has advocated and shown that, as interpretative systems and forms of knowledge concurring in the construction of a social reality, social representations are guides for action, influencing behaviours and social relations. Based on this assumption, the primary goal of the current study was to investigate the relationship between social representations of the development of intelligence and parenting styles, while also examining the role played by the values that parents desire for their children. The sample included 466 subjects with educational responsibilities (117 fathers, 227 mothers and 122 mother-teachers). Participants completed a self-administered survey on their representations of the development of intelligence, values desired for their children and parenting styles. A theoretical model which examined the relations among these variables was tested. Structural equation modelling procedures indicated, as hypothesized, that dimensions which emphasize the role of parents and the importance of constant accompaniment of children for the development of intelligence influence the authoritative parenting style, while dimensions which outline the role of school and teachers relate to authoritarian and permissive parenting styles. Additionally, although in some cases values were seen both to be determined by social representations and to influence parenting styles, the meditational hypothesis of values was not fully confirmed. Overall, the results obtained suggest that social representations, styles and values tend to build up a potentially significant organizations for parental activities. Theoretical and practical implications of these findings in research and educational intervention are discussed.

KEY WORDS: social representations; intelligence; parental values; parenting styles. 


\section{INTRODUCTION}

The study of ideas - whether representations, attitudes or beliefs - follows the history of psychology as one of the most researched dimensions explaining behaviour. Indeed, the links between thought and action are not a recent concern: current controversies have, in fact, been drawn throughout decades of investigation, which not only target this topic as an intense field of research, but also make it one of the most controversial. Underlying this research interest is the assumption of the existence of a coherent relationship between the content of ideas and related behaviour. It is within this perspective that research has been emphasizing that "social thinking is for doing" (Fiske, 1992, p. 877), as "people's interpersonal thinking is embedded in a practical context, which implies that it is best understood - and its accuracy best evaluated - by its observable and desired consequences for social behaviour" (p. 878).

Although the study of practices and behaviours is not an exclusive topic of concern and theoretical developments of the theory of social representations, one of the underlying principles of the theory focuses on the straight link between social representations and social practices, a fact which is made explicit in social representations' prescriptive function as guides for action (Abric, 1997, 2001; Jodelet, 1989a, 1989b; Moscovici, 1961). However, the close link between social representations and behaviour must be qualified in at least two ways (Wagner, 1993). First, social representations do not account for the behaviour of individuals per se, but only for the behaviour of individuals as members of social groups. Not disconsidering some degree of interindividual variability, their sociogenesis (Duveen \& Lloyd, 1990) of being collectively elaborated implies that social representations are valid systems of knowledge for groups as a whole and for the respective group members. Second, social representations are not conceived as cognitions simply intervening between stimulus and behaviour, but rather as symbolic structures comprising stimulus and behaviour in a simultaneous circular movement. As such, Moscovici (1984) strongly holds that representations do not mediate stimuli but are themselves stimuli and, hence, the independent variables in empirical investigations: "we must 
stress the firm stand that the theory of representations has taken in this respect: as far as social psychology is concerned, social representations are independent variables, explanatory stimuli" (p. 61).

"In social life the individuals rarely believe and act without implicitly or explicitly consulting the available social and cultural wisdom, that is, the shared knowledge and belief systems of the group or groups they belong to" (Wagner, 1993, p. 238). From this perspective, and while socially elaborated and shared systems of knowledge, social representations constitute the individuals' framework, the context in which they were socialized and from which they draw orientations for their social conduct and interaction.

Hence, studies on the relationship between social representations and behaviour have stemmed from the principle that a great deal of our behaviours correspond to our representations. In fact, knowing an individual's social representations relevant to a given situation tells a lot about the behaviour which can be expected. It is, therefore, a mutually descriptive relationship between representation and behaviour, a kind of "mapping between mental content and behaviour: the representation anticipates the socially relevant behaviour" (Wagner, 1993, p. 245). Indeed, central to the perspective of social representations is the belief that psychological states are socially produced and that representations influence reactions, since they provide a meaningful organization of reality and function as a system of interpretation that governs relationships between individuals and their physical and social environment. As representations influence both behaviour and practice, they thereby act as guides for action (Abric, 1997). In fact, several empirical studies have illustrated that the operational implications of representations extend right into the details of action (Abric, 1987; Doise, 1976; Faucheux \& Moscovici, 1968; Jodelet, 1989a; Voelklein \& Howarth, 2005).

Much of recent interest in parents' ideas has also stemmed from the conviction that there must be some relation between ideas and behaviours (Miller, 1988). Ideas are believed to organize the world for individuals, enabling them to cope with everyday life. In addition, ideas 
provide a means for generating behaviours that, in turn, may then affect the child's development, in response to parenting demands (Darling \& Steinberg, 1993). Set off by the assumption that ideas are the underlying force guiding parents' childrearing strategies and behaviours (McGillicuddy-De Lisi \& Sigel, 1995), research on the topic has expanded widely and already attracted several reviews (Goodnow, 1988; Goodnow \& Collins, 1990; Hirsjärvi \& PeräläLittunen, 2001; Miguel, Valentim, \& Carugati, 2009a; Okagaki \& Bingham, 2005; Sigel, McGillicuddy-De Lisi, \& Goodnow, 1992). Sources of interest have also widened. These changes have brought along several views taken as the possible bases for various cognitive aspects and emphasized different kinds of theory that might offer a useful conceptual backing.

One type of ideas is parenting goals, or the outcomes that parents hope to achieve while they are interacting with their children, and which are cited as pivotal in determining parenting behaviour (Hastings \& Grusec, 1998; Kuczynski, 1984). These goals include the types of values and qualities of life that parents hope their children will have as adults (Dix \& Branca, 2003). Indeed, irrespective of content or cultural variations, parents have certain values that they want to pass on to their children. For this reason, rather than being simply improvised, parental behaviour may be seen as highly guided by parental goals and values, as a way of achieving specific socialization goals for children. Indeed, research has long been interested in how parents impact child development (Ariès, 1962; Richards, 1926; Sears, Maccoby, \& Levin, 1957). However, finding actual cause-and-effect links between specific actions of parents and later behaviour has been a troublesome challenge. Baumrind's (1966, 1967, 1971, 1991, 2005) proposal on parenting styles has become an important and prominent contribution in research on parenting. Using naturalistic observation, parental interviews and questionnaires, she found two aspects deemed extremely important in shaping successful parenting: parental responsiveness and parental demandingness. From these, three general parenting styles were identified: authoritative, authoritarian, and permissive. Based on combinations of acceptance and control, further research has expanded this typology and suggested the addition of a fourth 
parenting style: authoritative, authoritarian, indulgent and neglectful (Maccoby \& Martin, 1983). Research based on Baumrind's three major prototypes of parenting has yielded a consistent picture of the types of parenting thought to enhance or mitigate the successful socialization of children. For example, authoritative parenting style has been shown to promote a positive overall development (Demo \& Cox, 2000; Steinberg, 2001), to assist young children and adolescents develop instrumental competence and academic success (Clémence, 2007; Clémence, et al., 2005; Dornbusch, Ritter, Leiderman, \& Roberts, 1987; Lamborn, Mounts, Steinberg, \& Dornbusch, 1991; Reitman, Rhode, Hupp, \& Altobello, 2002), to promote emotional and psychosocial development (Aunola, Stattin, \& Nurmi, 2000; Cohen \& Rice, 1997; Mandara \& Murray, 2002), and to prevent juvenile violence (Gorman-Smith, Tolan, Zelli, \& Huesmann, 1996) and drug consumption (Brooks, Stuewig, \& LeCroy, 1998).

In turn, special attention has also been devoted in identifying sources of variation in parenting styles. Research has assumed that parental behaviours and styles may also be influenced both by parental goals for children's education (Darling \& Steinberg, 1993), as well as by specific social representations concerning children development. As one of the most charged and valued psychological attributes in our society, a particularly pressing issue is the topic of intelligence development, especially for parents, teachers and the educational system in general, whose influence on intelligence represents an explicit goal. Over the years, empirical research has identified a multiplicity of common sense definitions of intelligence, building it up as a matter of social controversy and as a polysemic and many-sided topic. More precisely, the relativism and multidimensionality of intelligence has been illustrated by particularly featured definitional components of intelligence, such as, for example, a matter of natural inequalities and giftedness, as an expression of social skills and adaptability, as cognitive ability to solve problems - especially in logics and mathematics -, as an ability to critically integrate knowledge and information, or as the capacity to interpret and express emotions (Amaral, 1997; Constans \& Leonardis, 2003; Faria \& Fontaine, 1993; Miguel, Valentim, \& Carugati, 2008, 2010; Poeschl, 
1992; Raty \& Snellman, 1997; Raty, Snellman, \& Vornanen, 1993; Snellman \& Raty, 1995; Sternberg, 1985; Sternberg, Conway, Ketron, \& Bernstein, 1981). Furthermore, since Mugny and Carugati's (1985) seminal work on the social representations of intelligence and its development, research has systematically been confirming that psychosocial variables such as the shortage of information regarding the object of representation, the (un)familiarity with that object, the necessity of decision making and the maintenance of a positive social identity organize representations of intelligence, suggesting that the content of representations is directly linked to the activation of social roles and the salience of the object, leading individuals to modulate the opinions they express regarding intelligence (Amaral, 1997; Amaral, Vala, \& Carugati, 2004; Carugati, Selleri, \& Scappini, 1994; Miguel, et al., 2008, 2010).

Since educators' representations of both development in general and of specific tasks in particular may influence their behaviours in diversified contexts of action, it is surely not unreasonable to assume, as has been suggested (Mugny \& Carugati, 1985), that educators' ideas about intelligence and its development will have a major influence on their interventions with children. Based on these assumptions, the main goal of this study was to examine the relationship between social representations of the development of intelligence, parental values and parenting styles. More specific hypotheses are defined.

\section{Hypotheses}

As symbolic systems that allow individuals to interpret reality, social representations influence the relationship that individuals establish with their physical and social worlds. Considering a functional criterion (Vala, 2002), social representations are, therefore, taken as guides for action, which might influence individuals' behaviours and practices (Abric, 2001; Jodelet, 1989b; Mugny \& Carugati, 1985). In the specific case of intelligence, it might be reasonable to assume that social representations of the development of intelligence structure and orient educational action with children, especially in contexts where intelligence is a very 
prominent and salient topic. Hence, this line of reasoning led to the formulation of Hypothesis 1: social representations of the development of intelligence influence parenting styles. More specifically, representations which emphasize a high degree of parent/family influence in the development of intelligence might lead to an authoritative parenting style (Hypothesis 1a). On the other hand, representations which emphasize a high degree of influence of school and pressure on the child for the development of intelligence might lead to authoritarian and/or permissive parenting styles (Hypothesis 1b).

Parenting goals are acknowledged as guiding forces of parenting behaviour (Darling \& Steinberg, 1993; Hastings \& Grusec, 1998; Kuczynski, 1984). Following this body of literature, Hypothesis 2 was established: the values that parents desire for their children influence the parenting styles they adopt. More specifically, desired self-direction values might influence the adoption of the authoritative parenting style (Hypothesis 2a) and desired conformity values might influence the adoption of the authoritarian parenting style (Hypothesis $2 b$ ).

Sustained by formalized ideologies, personal experiences and daily communication, social representations allow systems of meaning to be shared, which convey a symbolic reality to the social world (Jodelet, 1989b; Jovchelovitch, 2007). In this context, the several ways of thinking about and educating children are developed according to collectively produced images framed by shared symbolic models, which define specific cultural contexts in which actors enact their representations or beliefs (Carugati, 1990a, 1990b; D'Alessio, 1990). Hence, considering, on the one hand, that parents educate their children in order to encourage the development of the necessary qualities for their roles as adults and, on the other hand, that desired values for children fit the symbolic reality which is socially and historically determined, the following Hypothesis 3 was suggested: social representations of the development of intelligence influence parental goals, namely the values that parents desire for their children. 
Considering the previous hypotheses, Hypothesis 4 was also defined: desired values for children mediate the relationship between social representations of the development of intelligence and parenting styles.

In general terms, a theoretical model as shown in Figure 1 was hypothesized.

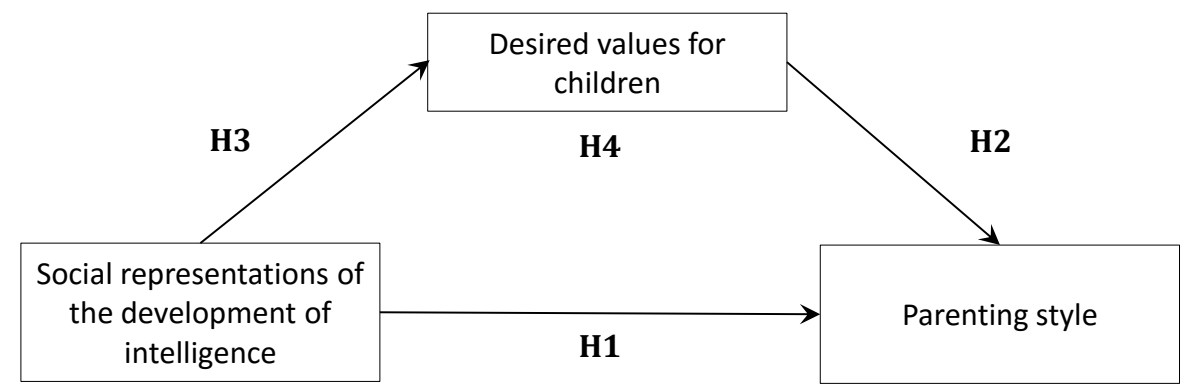

Figure 1 - Theoretical model

\section{METHOD}

\section{Sample}

This study involved 466 Portuguese participants with different educational responsibilities and social positions: 117 fathers, 227 mothers, 122 mother-teachers. Considering the whole sample, 117 participants were men (25\%) and 349 were women (75\%), ranging from 24 to 69 years old. Fathers presented a mean age of 40.39 ( $S D=5.76$; ages between 25 and 69 years old; mode $=36)$, mothers a mean age of $37.73(S D=4.49$; ages between 24 and 48 ; mode $=40)$ and mother-teachers a mean age of $41.89(S D=6.41$; ages between 29 and 60 ; mode $=38$ )

The overall sample presented a mean of 1.94 children per participant $(S D=.75)$, ranging from 1 to 6 children (observed minimum and maximum). All fathers and mothers had at least one child aged between 5 and 10 years old, attending an elementary school.

\section{Procedure}


Elementary schools were of great importance in collecting data from participants. After verbal and written contact with school members explaining the general goal of the investigation and asking their cooperation, questionnaires were handed to children to be taken home to their parents. After being filled in, around $70 \%$ of questionnaires were returned to school, again via the children.

On the first page, participants collaboration was requested and they were assured of the purely scientific context and purpose of the research. Participants were informed that their participation in the study was voluntary and confidential. All instructions were in writing and sufficiently detailed to enable the participants to answer the questionnaire on their own. Nonetheless, in order to assist the individual filling in of the questionnaire at home, the investigator's email contact was left in case of possible lack of understanding of instructions.

Participants and schools expressing a wish to be informed of the results of the research were assured that they would later be sent a report with the main conclusions.

\section{Measures}

The questionnaire included a demographic profile sheet which asked for the participant's age and sex, occupation, academic qualification, as well as the number and age of their children. The questionnaire itself consisted of three sub-questionnaires, which will be detailed next.

\section{Development of intelligence}

Subjects answered a total of 31 items by indicating the extent of agreement or disagreement on a seven-point scale $(1=$ totally disagree, $7=$ totally agree $)$. The process which led to the construction of the questionnaire on the development of intelligence stemmed from previous stages of our research (Miguel, et al., 2008, 2010), and from an extensive literature 
review (Amaral, 1997; Constans \& Leonardis, 2003; Faria \& Fontaine, 1993; Flament, 1999; Matteucci, 2007; Mugny \& Carugati, 1985; Poeschl, 1998, 1999, 2001; Sternberg, 1985, 2004; Sternberg, et al., 1981). Overall, several dimensions related to the development of intelligence were included in the questionnaire: parent, teacher and peer role in the development of intelligence (e.g., "parents are the child's main model for the development of his/her own intelligence", "teachers' competence is the best assurance of the child's development of intelligence", "in a group of children working together, they will develop their intelligence better than if they each work by themselves"), stimuli and challenge (e.g., "for the child to make progress, he/she has to be presented with challenges that stimulate him/her intellectually"), social and biological determinism (e.g., "intelligence does not develop, it is a hereditary gift"), autonomy (e.g., "in order to develop his/her intelligence the child must be autonomous"), affection (e.g., "the quality of affective relations between parents and children influences the development of intelligence"), communication and dialogue (e.g., "for the child to develop his/her intelligence, it is fundamental to dialogue with him/her about his/her behaviours"), social interaction (e.g., "interacting with other people is an essential element in the development of the child's intelligence"), motivational factors (e.g., "ambitious children reveal greater intellectual progress"), discipline (e.g., "the child's intellectual development is influenced by the awareness that parents have of appropriate studying schedules"), child control (e.g., "for the child to develop his/her intelligence, it is necessary that parents keep up with all his/her activities"), didactic games and materials (e.g., "the use of didactic games and materials - for example, puzzles or paper-and-pencil activities - stimulates the child's intellectual development").

Principal component analysis was performed on the items. Only items loading higher than .40 were retained (Stevens, 2002). Regarding this criterion, 19 items were considered for analysis. Three factors were extracted which, in combination, explained $42.4 \%$ of variance. The first component (8 items; Cronbach's alpha of $.773 ; 16.7 \%$ of total variance) puts special 
emphasis on a set of variables which relate to parent's role, namely affective equilibrium and disciplinary practices (e.g., "a permissive family environment compromises the development of intelligence"). The second component (5 items; Cronbach's alpha of .742; $14.2 \%$ of total variance) was named stimuli and incentives, since it expresses the idea that intelligence development is the result of a set of incentives and external motivational strategies that promote intellectual development (e.g., "it is by questioning and stimulating the child's reasoning that the development of intelligence can be promoted"). As for the third component (6 items; Cronbach's alpha of .624; $11.5 \%$ of total variance) - school, teachers and molding - it is school and teachers who are emphasized, within a context of formal education, where severity and pressure on children are accentuated as major factors for their intellectual development (e.g., "school is the main determinant in the development of intelligence").

\section{Parenting styles}

Following the prominent use of parenting styles in research on parenting, a modified version of the Parenting Styles and Dimensions Questionnaire - Short Form (PSDQ; Robinson, Mandleco, Olsen, \& Hart, 2001) was used. This instrument was primarily developed to overcome limitations of other widely used parenting style measures for school-aged children, which were acknowledged to a) contain a large number of determined factors, b) comprising many items which could be outdated or inconsistent with the literature and c) using conceptual guidelines rather than empirical derivations (Robinson, Mandleco, Olsen, \& Hart, 1995). The reduced PSDQ included 32 items consistent with Baumrind's (1967, 1971, 1991, 2005) authoritative, authoritarian and permissive typologies of parenting behaviour. The authoritative pattern was composed of three stylistic dimensions: (a) warmth/acceptance (connection) (e.g. gives praise, comfort and understanding), 5 items; (b) reasoning (regulation) (e.g., gives child reasons why rules should be obeyed), 5 items; and (c) democratic participation (autonomy granting) (e.g., allows child to give input into family rules), 5 items. The authoritarian pattern consisted of three 
stylistic dimensions: (1) verbal hostility (e.g., yells and shouts when child misbehaves), 4 items; (2) physical coercion (e.g., spanks when child is disobedient), 4 items; and (3) nonreasoning/punitive (e.g., punishes by taking privileges away from child with little if any explanations), 4 items. The permissive pattern consisted of a single stylistic dimension: indulgent (e.g., states punishments to child and does not actually carry them out), 5 items.

The Portuguese adaptation of the PSDQ - Short Form (Miguel, Valentim, \& Carugati, 2009b) began with the translation of the original version according to the translate-translate back method (Hill \& Hill, 2000). A number of concerns regarding comprehensibility and cultural sensitivity were raised, and modifications were subsequently made to enhance the validity of the measure. After the Portuguese version was assured to be adequate, participants were asked to independently rate themselves on each item by assessing "how often they perceived themselves exhibiting parenting behaviours reflected in each item" using a 5-point scale anchored by 1 (never) and 5 (always).

Scales contained three to five items for each stylistic dimension and therefore were deemed adequate for Structural Equation Modeling - SEM (Kline, 1998). Hence, the latent structure underlying the appraisal items was assessed in a confirmatory factor analysis (CFA) using EQS software. A three-factor model was tested, where each item was allowed to load only on its designated factor. After controlling for the non-normality of data through robust correction, fit indices (Hu \& Bentler, 1999; Kline, 1998) demonstrated that the original structure of the instrument fitted the data well. However, the review of the LM Test (Lagrange Multiplier Test - Multivariate Statistics) values revealed an error covariance between items 31-29 and 326 to contribute most to any misfit in the model. Items 29 and 31 referred to communicating with the child about the consequences of behaviours and items 6 and 32 concerned physical punishment in situations of disobedience or misbehaviour. Given the apparent content overlap of items, the specification of an error covariance between these pairs of items was argued to be substantially reasonable and, therefore, estimation of these parameters was added to the 
model. The PSDQ structure as specified in the reviewed model represents a very adequate fit to the data (see Table 1). The standardized factor loadings also confirmed that each factor was well defined by its items.

Table 1. Parenting Styles and Dimensions Questionnaire: CFA Fit Indices

\begin{tabular}{lcccccc}
\hline & \multicolumn{7}{c}{ Fit indices } \\
\cline { 2 - 7 } & $\mathrm{S}-\mathrm{B} \chi^{2}$ & $\mathrm{df}$ & $\mathrm{S}-\mathrm{B} \chi^{2} / \mathrm{df}$ & $\mathrm{CFI}$ & $\mathrm{NNFI}$ & RMSEA \\
\hline Initial model & 639.42 & 453 & 1.41 & .94 & .93 & .032 \\
Reviewed model & 604.12 & 451 & 1.34 & .95 & .94 & .029 \\
\hline
\end{tabular}

NOTE: $S-B \chi^{2}=$ Satorra-Bentler $\chi^{2} ; \mathrm{CFI}=$ Comparative Fit Index; NNFI = Non-Normed Fit Index; RMSEA = Root Mean Square Error of Approximation.

Cronbach's alpha was calculated for the three parenting styles. Results showed high reliabilities for the authoritative (.84) and authoritarian (.78) patterns. The permissive parenting style (.64) presented a lower consistency. Generally speaking, the obtained alphas were very similar to the original version of the PSDQ (Robinson, et al., 2001), which yielded values of .86, .82 and .64 respectively for authoritative, authoritarian and permissive parenting styles.

\section{Parental values}

The Parental Values Scale (Castro, 1997) is a research tool developed to assess the values that parents desire for their children. Using a 5 -point scale $(1=$ not important; $5=$ very important), participants were asked to rate how important is was for them that their child would display six different characteristics when adults: independent, creative and with self-made ideas (self-direction values); obedient, respectful of the elderly and good parents/spouses (conformity values).

CFA was used to assess the underlying structure of the instrument. Given the nonnormality of data, the hypothetical model was submitted to a robust correction of data (Byrne, 
2006). Initial results indicated an ill-fitting model. Given that some modification in specification was needed to determine a model that better represented the sample data, LM Test statistics were analysed, which suggested error covariance between items 3 ("obedient") and 5 ("with self-made ideas") to be freely estimated in a subsequent run. After freely estimating this parameter, the reviewed model presented a perfect fit index (Hu \& Bentler, 1999) of the data (Table 2). The moderate and high standardized factor loadings also confirmed that each factor was well defined by its items.

Table 2. Parental Values: CFA Fit Indices

\begin{tabular}{lcccccc}
\hline & \multicolumn{7}{c}{ Fit indices } \\
\cline { 2 - 7 } & $\mathrm{S}-\mathrm{B} \chi^{2}$ & $\mathrm{df}$ & $\mathrm{S}-\mathrm{B} \chi^{2} / \mathrm{df}$ & $\mathrm{CFI}$ & $\mathrm{NNFI}$ & RMSEA \\
\hline Initial model & 24.33 & 8 & 3.04 & .93 & .86 & .067 \\
Reviewed model & 6.59 & 7 & .93 & 1.0 & 1.0 & .000 \\
\hline
\end{tabular}

NOTE: $S$-B $\chi^{2}=$ Satorra-Bentler $\chi^{2} ; \mathrm{CFI}=$ Comparative Fit Index; NNFI = Non-Normed Fit Index; RMSEA = Root Mean Square Error of Approximation.

\section{RESULTS}

To examine the relationship between social representations of the development of intelligence, desired values for children and parenting styles, the structural model was tested with EQS software. The analyses were carried out using the matrix of the original data as input and the maximum likelihood procedure. Diverse indexes have been suggested to test the goodness of fit of the model, such as the chi-square statistic, $\chi^{2}$, the value of which should be nonsignificant $(p>.05)$ in order to indicate that the proposed model fits the data. Due to the sensitivity of the chi-square statistic to sample size, other absolute fit indexes were proposed, such as $\chi^{2} /$ degrees of freedom, where values lower than 3 indicate a good fit (Kline, 1998; Ullman, 2001). Likewise, the Comparative Fit Index (CFI) and the Goodness of Fit Index (GFI) are suggested, whose threshold value is .95 to consider that the proposed model has a good fit ( $\mathrm{Hu}$ 
\& Bentler, 1999). The Root Mean Square Error of Approximation (RMSEA) is also recommended, which is a measure of model discrepancy by degrees of freedom, whose values should be lower than $.06, .08$ or .10 , respectively to indicate a very good, a good and an acceptable fit (Byrne, 2006; Hu \& Bentler, 1999; Kline, 1998). Values lower than .10 for the Standardized Root Mean Square Residual (SRMR) also indicate a good fit (Kline, 1998).

Results demonstrate that the models fit the data well. For the model considering the authoritative parenting style, fit indices showed excellent fit: $\mathrm{CFI}=.951 ; \mathrm{GFI}=.985 ;$ SRMR $=.045$ and RMSEA $=.073$ (Figure $2-$ model $a$ ). The same for the authoritarian parenting style model: $\mathrm{CFI}=.935, \mathrm{GFI}=.981, \mathrm{SRMR}=.046$ and RMSEA $=.066$ (Figure 2 -model $b)$. Also the model considering the permissive parenting style displayed very good fit: $\mathrm{CFI}=.948, \mathrm{GFI}=.984$, SRMR $=.043$ and RMSEA $=.055$ (Figure $2-$ model $c$ ). Standardized parameter estimates are shown in the figure.

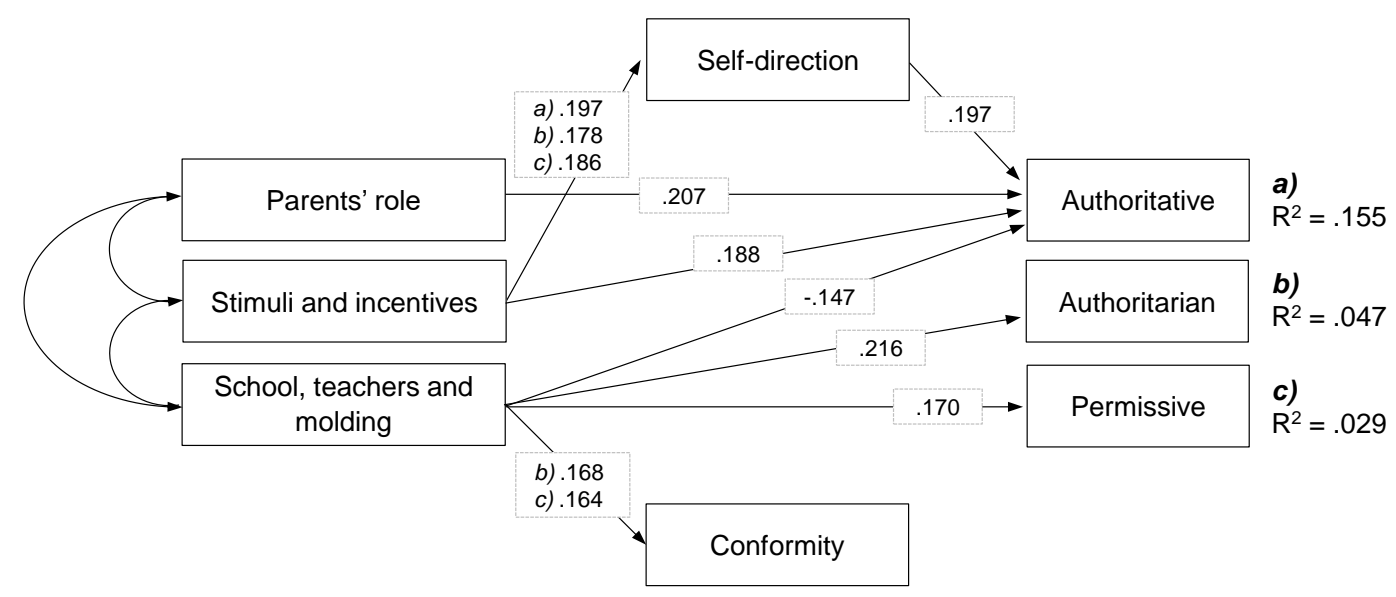

Figure 2. Path model relating to the social representations of the development of intelligence

a) a model of desired values and authoritative parenting style $\left(\chi^{2}(6, N=466)=19.120, p<.01 ; C F I=.951\right.$; $\mathrm{GFI}=.985 ; \mathrm{SRMR}=.045 ; \mathrm{RMSEA}=.073$ )

b) a model of desired values and authoritarian parenting style $\left(\chi^{2}(9, N=466)=24.942, p<.01 ; \mathrm{CFI}=.935\right.$; $\mathrm{GFI}=.981 ; \mathrm{SRMR}=.046 ; \mathrm{RMSEA}=.066$ )

c) a model of desired values and permissive parenting style. $\chi^{2}(9, N=466)=20.826, p<.01$; CFI = .948; GFI $=.984 ;$ SRMR $=.043 ;$ RMSEA $=.055$ )

NOTE: Only significant $(p<.05)$ standardized parameter estimates are shown. 
In accordance with Hypothesis 1a, parents' role and stimuli and incentives were significant predictors of the authoritative parenting style (model a). In the same vein, the significant connections between school, teachers and molding and the authoritarian (model $b$ ) and permissive (model $c$ ) parenting styles lend empirical support to Hypothesis 1b. Additionally, the authoritative parenting style is negatively influenced by school, teachers and molding, which, although not established in the initial hypotheses, can be understood considering the overall results.

The positive significant path between self-direction values and the authoritative parenting style lends support to hypothesis 2 a (model $a$ ). However, results do not support hypothesis $2 b$.

The factor stimuli and incentives was a significant predictor of self-direction values in all models considered (models $a, b$ and $c$ ). In turn, conformity values are only influenced by school, teachers and molding in the models that take the authoritarian (model $b$ ) and the permissive (model c) parenting styles as dependent variables. Overall, results lend empirical support to hypothesis 3.

The mediating role of desired values for children (Hypothesis 4) was only found for the authoritative parenting style.

\section{DISCUSSION}

The nature of the relationship between social representations and practices has constituted a major theoretical issue in understanding social phenomena. Based on the assumption that representations extend into the details of action, the main goal of the present study was to test a theoretical model which examines the relations between social representations of the development of intelligence, parental values and parenting styles. 
Results provided concerning the impact of social representations of the development of intelligence on parenting styles suggest the importance of studying the relation between representations and behaviours. According to the theoretical model hypothesized, results altogether lead to the conclusion that the type of relationship and parenting styles that parents report having with their children is influenced by their representations about the development of intelligence, as well as by their desired values for children. The multiple definitions and ideas concerning intelligence and its development seem, therefore, to determine behavioural patterns with children reported by parents.

However, results suggest other possible implications. For example, agreeing or disagreeing with the idea that school is the main responsible for children's education and that the most effective way of teaching children is by repeating basic information many times might have consequences not only for the type of relationship with children, but also on the type of relationship that parents establish with school. Therefore, while maintaining an authoritarian behaviour - probably based on systematic repetition of school contents - the positive path found between the representation of school as the main determinant in the development of children's intelligence and the permissive parenting style might suggest that participants are clearly proposing a distant and non-intervening relation with school, leaving to it the responsibility for children's formal teaching and education, a fact that seems to be in line with previous results (Miguel, et al., 2010; Miguel, Valentim, \& Carugati, in press). Nevertheless, three additional remarks should be considered. First, research has also shown that children's overall development, in terms of their socialization and socio-emotional maturity, is considered to be a major important family responsibility. For example, it has been shown that both mothers and mother-teachers highly appreciate the importance of the parents' role in establishing discipline rules and a appropriate communication with children, therefore underlining the importance of their own educational role in their children's development of intelligence (Miguel, et al., in press). Also, the mother's privileged acceptance of a definition of intelligence as the adaptation 
to social norms, conformism and social integration (Miguel, et al., in press) might transmit the importance ascribed to their own role as a socialization agent and to the transmission of socially defined rules, associated to the belief of intelligence as a legacy of the family values system (Faria \& Fontaine, 1993). Second, research has consistently demonstrated, on the other hand, that the degree of proximity to the object of representation, which stems from different social positions - e.g. mother and mother-teachers - introduces systematic variations in the weight social groups give to different dimensions underlying the structure of representations of intelligence and its development. For instance, mother-teachers have been identified as stressing a definition of intelligence as an ability to solve concrete and abstract problems and to claim the importance of constant stimulation and incentives for the development of intelligence. Also, their attempt to maintain positive self-esteem and identity is illustrated in their rejection of teachers' competence as an important source of children's academic failure, while also devaluing the responsibility of school and teachers and the effectiveness of modelling strategies for the development of intelligence (Amaral, 1997; Miguel, et al., 2008, 2010, in press; Mugny \& Carugati, 1985). Third, in the studied samples, fathers have been recognized as presenting more undefined representations, especially when compared to mothers and mother-teachers, suggesting an effect of gender on overall representations of intelligence and its development and that fatherhood does not carry the same kind of implications and conflict as for subjects with a motherhood status (Miguel, et al., in press). In fact, research has been consistent in showing that motherhood still has a more preponderant social value and that dominant cultural models still relate women to the family context and higher involvement in childrearing (Múrias \& Ribeiro, 2012; Pedro, 2010; Poeschl, 2000). Therefore, generally considered, results emphasize that parents, as such, may not constitute such a homogeneous social group, calling for further research on the influence of other variables (e.g., gender, socioeconomic status and education) in the variation of results (see also Valentim, 1997). 
As it can be seen in the results, the standardized path coefficients relating the different explanations concerning the development of intelligence and parenting styles may indicate a moderate effect (Kline, 1998). Nevertheless, the explained level of variance of the three parenting styles is very low. However, these scores can be understood if we consider that parental functioning is multiply determined. The literature (Belsky, 1984; Belsky \& Jaffe, 2006) has indeed highlighted three domains of determinants of parenting behaviour, namely those concerning the personal and psychological resources of parents, characteristics of the child and contextual sources of stress. Therefore, parental ideas and representations on the development of intelligence are only one of the numerous factors influencing how parents respond to their children.

Although maintaining systematically low levels, the authoritative parenting style is the one that, of them all, has the highest level of explained variance. In this sense, we might be brought to consider that, dealing with participants' reported behaviour (and, therefore, not observed by the investigator), some answers might have been given in a way that would be favourably viewed by others, taking the form of overreporting good behaviour or underreporting bad. Since the authoritative parenting style is viewed as more socially acceptable than the authoritarian and permissive styles, this might explain the highest explained variance for the authoritative parenting pattern. This verity has already been acknowledged by Maccoby and Martin (1983) who emphasize the fact that, as far as relying on the responsibilities of parents to self-analyse and describe their own behaviours and the contexts in which they occur, the methodologies that are based on parents as source of information are subject to criticism regarding the reliability and validity of information. However, although these limitations can be accepted, we cannot but agree with Rubin and Mills (1992) when they state that "after all, the disconnection between observed and self-report behaviour is common to almost all areas of study in psychology" (p. 42) and is, therefore, not specific to studies on parenting styles. 
Social representations are not just taken as a set of cognitions intervening between stimuli and behaviour, but rather as symbolic structures which integrate themselves into stimuli and behaviours in circular and simultaneous movements. In this sense, and as suggested by Moscovici (1984), "rather than motivations, aspirations, cognitive principles and the other factors that are usually put forward, it is our representations which, in the last resort, determine our reactions" (p. 65). In this sense, social representations are themselves the stimuli and, therefore, the independent variables of empirical research that seek to explain collective behaviour at a group level, or the behaviour of individuals as members of a certain social group. Nevertheless, although the results of the present study allowed us to explore the influence of social representations on practices, the interpretation of these data needs to be cautious. In fact, one needs to bear in mind that the relationships between social representations and practices, far from being unequivocal and unidirectional, are extremely complex and the product of numberless factors, with practices often being suggested, not as the result, but rather as the source of social representations (Almeida, Santos, \& Trindade, 2000; Sá, 1994). Considering this possibility, we might have to assume that parenting styles may also influence social representations of intelligence and its development. Therefore, from this point of view, considering that the assessment of parenting styles resulted from participants' behavioural selfreport, the social representations might have developed in the sequence of practices, as $a$ posteriori justification of reported parenting styles. Indeed, concerning the old and troublesome relation between parental ideas and actions, the literature has pointed to an alternate direction of effect: that ideas follow - and not precede - actions, suggesting that action can come about without much grounding in thought, as ideas are prompted by people's actions to develop justifications, either to others or to themselves (Festinger \& Carlsmith, 1959; Goodnow \& Collins, 1990; Russell \& Russell, 1988). Considering the complexity of the parental idea-behaviour dilemma, efforts have been made to unravel this relation and to point out limitations of current research (see also Miguel, et al., 2009a). 
A suggestion has been made to challenge the interpretation of social representations as solely cognitive phenomena (Howarth, 2006), since consequences of social representations go far beyond the cognitive and can "produce extremely concrete and real consequences in people's lives" (Jovchelovitch, 2001, p. 177). Altogether, the results of the present study provide empirical support for the relationship between psychological processes and social practices, by showing how social representations of the development of intelligence are often apparent in parenting styles and action. Theoretical and practical implications of these findings in research and educational intervention must, therefore, be considered. Teachers, for example, make sense of their complex world and respond to it by forming a complex system of personal and professional knowledge and theories in which assumptions about students, classrooms and ways of teaching are often implicitly held. The literature points to the fact that teachers' implicit theories about education are powerful forces in shaping their decisions and practice in the classroom (Berry, 2006; Carugati \& Selleri, in press; Laplante, 1997; Selleri \& Carugati, in press; Stanovich \& Jordan, 1998; Valentim, 1997). The recognition that representations permeate teaching practices reinforces confidence that reconceptualizing implicit theories may enhance more effective instructional strategies. As for parents, the literature has long discussed the consequences of parents' ideas both for parents and for children. In fact, empirical evidence has been provided for the important role of parental ideas as determinants of parental actions and behaviours (for a review, see Miguel, et al., 2009a; Raty, Kasanen, \& Honkalampi, 2006) and for the effects of parenting practices and styles on child outcomes and behaviours (Clémence, 2007; Cohen \& Rice, 1997; Demo \& Cox, 2000; English, 1998; Lamborn, et al., 1991; Reitman, et al., 2002; Steinberg, 2001). Given the clear implications for educational practice, a new field in terms of school and parental research and intervention is opened. 


\section{References}

Abric, J.-C. (1987). Coopération, compétition et représentations sociales. Cousset: DelVal.

Abric, J.-C. (1997). Pratiques sociales, représentations sociales. In J.-C. Abric (Ed.), Pratiques sociales et représentations (2nd ed., pp. 217-238). Paris: Presses Universitaires de France.

Abric, J.-C. (2001). A structural approach to social representations. In K. Deaux \& G. Philogène (Eds.), Representations of the social: Bridging theoretical traditions (pp. 42-47). Oxford: Blackwell.

Almeida, A. M., Santos, M. F., \& Trindade, Z. (2000). Representações e práticas sociais: Contribuições teóricas e dificuldades metodológicas. Temas em Psicologia, 8(3), 257-267.

Amaral, V. (1997). A inteligência e o seu desenvolvimento: Representações sociais e identidades sociais. In M. B. Monteiro \& P. Castro (Eds.), Cada cabeça sua sentença: Ideias dos adultos sobre as crianças (pp. 33-74). Oeiras: Celta.

Amaral, V., Vala, J., \& Carugati, F. (2004). Perspectivas "desenvolvimentistas" e de género acerca das representações sociais da inteligência. In J. Vala, M. Garrido \& P. Alcobia (Eds.), Percursos de investigação em psicologia social e organizacional (Vol. I, pp. 91-106). Lisboa: Edições Colibri.

Ariès, P. (1962). Centuries of childhood. New York: Vintage Books.

Aunola, K., Stattin, H., \& Nurmi, J. E. (2000). Parenting styles and adolescents achievement strategies. Journal of Adolescence, 23, 205-222.

Baumrind, D. (1966). Effects of authoritative parental control on child behavior. Child Development, 37, 255-272.

Baumrind, D. (1967). Child care practices anteceding three patterns of pre-school behaviour. Genetic Psychology Monographs, 75, 43-88.

Baumrind, D. (1971). Current patterns of parental authority. Developmental Psychology Monograph, 4(1), 1-103.

Baumrind, D. (1991). The influence of parenting style on adolescent competence and substance abuse. Journal of Early Adolescence, 11(1), 56-95.

Baumrind, D. (2005). Patterns of parental authority and adolescent autonomy. New Directions for Child and Adolescent Development, 108, 61-69.

Belsky, J. (1984). The determinants of parenting: A process model. Child Development, 55, 83-96.

Belsky, J., \& Jaffe, S. (2006). The multiple determinants of parenting. In D. Cichetti \& D. A. Cohen (Eds.), Developmental psychopathology (2nd ed., Vol. 3: Risk, disorder and adaptation, pp. 38-85). New York, NY: Wiley.

Berry, R. A. (2006). Beyond strategies: Teacher beliefs and writing instruction in two primary inclusion classrooms. Journal of Learning Disabilities, 39(1), 11-24.

Brooks, A., Stuewig, J., \& LeCroy, C. (1998). A family based model of Hispanic adolescent substance use. Journal of Drug Education, 28, 65-86.

Byrne, B. M. (2006). Structural equation modeling with EQS: Basic concepts, applications and programming (2nd ed.). Mahwah, NJ: Lawrence Erlbaum Associates. 
Carugati, F. (1990a). Everyday ideas, theoretical models and social representations: The case of intelligence and its development. In G. R. Semin \& K. J. Gergen (Eds.), Everyday understanding: Social and scientific implications (pp. 130-150). London: Sage Publications.

Carugati, F. (1990b). From social cognition to social representations in the study of intelligence. In G. Duveen \& B. Lloyd (Eds.), Social representations and the development of knowledge (pp. 126143). Cambridge: Cambridge University Press.

Carugati, F., \& Selleri, P. (in press). Social development and the development of social representations: Two sides of the same coin? In A. Antonietti, E. Confalonieri \& A. Marchetti (Eds.), Metarepresentation and narrative in educational settings: Where cognitive and social development meet. London: Psychology Press \& Routledge.

Carugati, F., Selleri, P., \& Scappini, E. (1994). Are social representations an architecture of cognitions? A tentative model for extending the dialog. Papers on Social Representations, 3(2), 134-151.

Castro, P. (1997). Mães e profissionais: Exercícios em equilíbrio. In M. B. Monteiro \& P. Castro (Eds.), Cada cabeça sua sentença: Ideias dos adultos sobre as crianças (pp. 9-32). Oeiras: Celta.

Clémence, A. (2007). Les modèles d'éducation parentaux. Psychoscope, 28(4), 16-18.

Clémence, A., Kaiser, C.-A., Modak, M., Nicolet, M., Zittoun, T., Biétry, V., et al. (2005). Les modèles de l'exercice de l'autorité dans la famille et dans l'école. In Collectif (Ed.), Eloge de l'altérité. Défis de société: 12 regards sur la santé, la famille et le travail (pp. 165-175). Grolley: Les Éditions de I'Hèbe.

Cohen, D. A., \& Rice, J. (1997). Parenting styles, adolescent substance use and academic achievement. Journal of Drug Education, 27, 199-211.

Constans, S., \& Leonardis, M. (2003). Co-construction of the representations of intelligence between mother and daughter: Developmental and differential approaches. European Journal of Psychology of Education, 18(4), 369-387.

D'Alessio, M. (1990). Social representations of childhood: An implicit theory of development. In G. Duveen \& B. Lloyd (Eds.), Social representations and the development of knowledge (pp. 70-90). Cambridge: Cambridge University Press.

Darling, N., \& Steinberg, L. (1993). Parenting style as context: An integrative model. Psychological Bulletin, 113(3), 487-496.

Demo, D. H., \& Cox, M. J. (2000). Families with young children: A review of research in the 1990s. Journal of Marriage and the Family, 62, 867-895.

Dix, T., \& Branca, S. H. (2003). Parenting as a goal-regulation process. In L. Kuczynski (Ed.), Handbook of the dynamics in parent-child relations (pp. 167-187). Thousand Oaks, CA: Sage.

Doise, W. (1976). L'articulation psychosociologique et les relations entre groupes. Bruxelles: De Boeck.

Dornbusch, S. M., Ritter, P. L., Leiderman, P. H., \& Roberts, D. F. (1987). The relation of parenting style to adolescent school performance. Child Development, 58, 1244-1257.

Duveen, G., \& Lloyd, B. (1990). Introduction. In G. Duveen \& B. Lloyd (Eds.), Social representations and the development of knowledge (pp. 1-10). Cambridge: Cambridge University Press.

English, D. (1998). The extent and consequences of child maltreatment. The Future of Children, 8(1), 3951. 
Faria, L., \& Fontaine, A. M. (1993). Representações dos professores sobre a natureza e desenvolvimento da inteligência. Revista Portuguesa de Pedagogia, 3, 471-487.

Faucheux, C., \& Moscovici, S. (1968). Self-esteem and exploitative behaviour in a game against chance and nature. Journal of Personality and Social Psychology, 8, 83-88.

Festinger, L., \& Carlsmith, J. M. (1959). Cognitive consequences of forced compliance. Journal of Abnormal and Social Psychology, 58, 203-210.

Fiske, S. (1992). Thinking is for doing: Portraits of social cognition from daguerreotype to laserphoto. Journal of Personality and Social Psychology, 63(6), 877-889.

Flament, C. (1999). Liberté d'opinion et limite normative dans une représentation sociale: Le développement de l'intelligence. Swiss Journal of Psychology, 58(3), 201-206.

Goodnow, J. J. (1988). Parents' ideas, actions and feelings: Models and methods from developmental and social psychology. Child Development, 59, 286-320.

Goodnow, J. J., \& Collins, W. A. (1990). Development according to parents: The nature, sources and consequences of parents' ideas. Hove: Lawrence Erlbaum Associates Ltd.

Gorman-Smith, D., Tolan, P. H., Zelli, A., \& Huesmann, R. L. (1996). The relations of family functioning to violence among inner-city minority youths. Journal of Family Psychology, 10, 115-129.

Hastings, P. D., \& Grusec, J. E. (1998). Parenting goals as organizers of responses to parent- child disagreement. Developmental Psychology, 34(3), 465-479.

Hill, M. M., \& Hill, A. (2000). Investigação por questionário. Lisboa: Edições Sílabo.

Hirsjärvi, S., \& Perälä-Littunen, S. (2001). Parental beliefs and their role in child-rearing. European Journal of Psychology of Education, 16(1), 87-116.

Howarth, C. (2006). A social representations is not a quiet thing: Exploring the critical potential of social representations theory. British Journal of Social Psychology, 45, 65-86.

Hu, L., \& Bentler, P. M. (1999). Cutoff criteria for fit indexes in covariance structure analysis: Conventional criteria versus new alternatives. Structural Equation Modeling, 6, 1-55.

Jodelet, D. (1989a). Folies et représentations sociales. Paris: PUF.

Jodelet, D. (1989b). Représentations sociales: Un domaine en expansion. In D. Jodelet (Ed.), Les représentations sociales (pp. 30-62). Paris: Presses Universitaires de France.

Jovchelovitch, S. (2001). Social representations, public life and social construction. In K. Deaux \& G. Philogène (Eds.), Representations of the social: Bridging theoretical traditions (pp. 165-182). Oxford: Blackwell.

Jovchelovitch, S. (2007). Knowledge in context: Representations, community and culture. Hove, East Sussex: Routledge.

Kline, R. B. (1998). Principles and practice of structural equation modeling. New York: The Guilford Press.

Kuczynski, L. (1984). Socialization goals and mother-child interaction: Strategies for long-term and shortterm compliance. Developmental Psychology, 20(6), 1061-1073. 
Lamborn, S. D., Mounts, N. S., Steinberg, L., \& Dornbusch, S. M. (1991). Patterns of competence and adjustment among adolescents from authoritative, authoritarian, indulgent and neglectful families. Child Development, 62, 1049-1065.

Laplante, B. (1997). Teachers' beliefs and instructional strategies in science: Pushing analysis further. Science Education, 81(3), 277-294.

Maccoby, E. E., \& Martin, J. A. (1983). Socialization in the context of the family: Parent-child interaction. In E. M. Hetherington (Ed.), Handbook of child psychology (Vol. 4, pp. 1-101). New York: John Wiley \& Sons.

Mandara, J., \& Murray, C. B. (2002). Development of an empirical typology of African American family functioning. Journal of Family Psychology, 16(3), 318-337.

Matteucci, M. C. (2007). Teachers facing the school failure: The social valorization of effort in the school context. Social Psychology of Education, 10, 29-53.

McGillicuddy-De Lisi, A. V., \& Sigel, I. E. (1995). Parental beliefs. In M. H. Bornstein (Ed.), Handbook of parenting. Status and social conditions of parenting (Vol. 3, pp. 333-358). Mahwah, NJ: Lawrence Erlbaum Associates.

Miguel, I., Valentim, J. P., \& Carugati, F. (2008). Representações sociais da inteligência e práticas educativas: Apresentação de uma investigação em curso. In A. Caetano, M. Garrido, S. Batel \& A. M. Martins (Eds.), Percursos da investigação em psicologia social e organizacional (Vol. III, pp. 301-318). Lisboa: Edições Colibri.

Miguel, I., Valentim, J. P., \& Carugati, F. (2009a). Parental ideas and their role in childrearing: The ideabehavior connection. Italian Journal of Sociology of Education, 3, 225-253.

Miguel, I., Valentim, J. P., \& Carugati, F. (2009b). Questionário de Estilos e Dimensões Parentais - Versão Reduzida: Adaptação portuguesa do Parenting Styles and Dimensions Questionnaire - Short Form. Psychologica, 51, 169-188.

Miguel, I., Valentim, J. P., \& Carugati, F. (2010). Intelligence and its development: Social representations and social identities. Papers on Social Representations, 19, 20.21-20.33.

Miguel, I., Valentim, J. P., \& Carugati, F. (in press). The degree of proximity in the construction of social representations: The case of intelligence. Spanish Journal of Psychology.

Miller, S. (1988). Parents' beliefs about children's cognitive development. Child Development, 59, 259285.

Moscovici, S. (1961). La psychanalyse, son image et son publique. Paris: PUF.

Moscovici, S. (1984). The phenomenon of social representations. In R. Farr \& S. Moscovici (Eds.), Social representations (pp. 3-69). Cambridge: Cambridge University Press.

Mugny, G., \& Carugati, F. (1985). L'Intelligence au pluriel: Les représentations sociales de l'intelligence et de son développement. Cousset: Editions DelVal.

Múrias, C., \& Ribeiro, R. (2012). Ideias a desconstruir ou a reinventar: Questionando percursos tradicionais de liderança de mulheres e de homens. In C. Múrias \& M. Koning (Eds.), Lideranças partilhadas: Percursos de literacia para a igualdade de género e qualidade de vida (pp. 201-222). Porto, Portugal: LivPsic. 
Okagaki, L., \& Bingham, G. E. (2005). Parents' social cognitions and their parenting behaviors. In T. Luster \& L. Okagaki (Eds.), Parenting: An ecological perspective (2nd ed., pp. 3-33). Mahwah, NJ: Lawrence Erlbaum Associates.

Pedro, I. (2010). Funções parentais no processo educativo e de escolarização dos filhos. Unpublished Tese de Doutoramento, Universidade do Porto, Porto.

Poeschl, G. (1992). L'intelligence: Un concept à la recherche d'un sens. Étude de l'éffet du processus d'ancrage sur la représentations sociale de líntelligence. Université de Genève, Genève.

Poeschl, G. (1998). Processus d'ancrage et représentations sociales de l'intelligence. Psicologia, 12, 85100.

Poeschl, G. (1999). Intelligence masculine et intelligence féminine. In B. Bril, P. Dasen, C. Sabatier \& B. Krewer (Eds.), Propos sur l'enfant et I'adolescent: Quels enfants por quelles cultures? (pp. 297315). Paris: L'Harmattan.

Poeschl, G. (2000). Trabalho doméstico e poder familiar: Práticas, normas e ideais. Análise Social, 15, 695719.

Poeschl, G. (2001). Social comparison and differentiation strategies in social representations of intelligence. Swiss Journal of Psychology, 60(1), 15-26.

Raty, H., Kasanen, K., \& Honkalampi, K. (2006). Three years later: A follow-up study of parents' assessments of their children's competencies. Journal of Applied Social Psychology, 36(9), 20792099.

Raty, H., \& Snellman, L. (1997). Children's images of an intelligent person. Journal of Social Behavior and Personality, 12(3), 773-784.

Raty, H., Snellman, L., \& Vornanen, A. (1993). Public views on intelligence: A Finnish study. Psychological Reports, 72, 59-65.

Reitman, D., Rhode, P. C., Hupp, S. D., \& Altobello, C. (2002). Development and validation of the Parental Authority Questionnaire - Revised. Journal of Psychopathology and Behavioral Assessment, 24(2), 119-127.

Richards, E. L. (1926). Practical aspects of parental love. Mental Hygiene, 10, 225-241.

Robinson, C. C., Mandleco, B., Olsen, S. F., \& Hart, C. (1995). Authoritative, authoritarian and permissive parenting practices: Development of a new measure. Psychological Reports, 77, 819-830.

Robinson, C. C., Mandleco, B., Olsen, S. F., \& Hart, C. H. (2001). The Parenting Styles and Dimensions Questionnaire (PSDQ). In B. F. Perlmutter, J. Touliatos \& G. W. Holden (Eds.), Handbook of family measurement techniques (Vol. 3. Instruments and index, pp. 319-321). Thousand Oaks: Sage.

Rubin, K. H., \& Mills, R. S. (1992). Parents' thoughts about children's socially adaptive and maladaptive behaviors: Stability, change and individual differences. In I. E. Sigel, A. V. McGillicuddy-De Lisi \& J. Goodnow (Eds.), Parental beliefs systems: The psychological consequences for children (2nd ed., pp. 41-69). Hillsdale, NJ: Lawrence Erlbaum Associates.

Russell, A., \& Russell, G. (1988). Mothers' and fathers' explanations of observed interactions with their children. [doi: 10.1016/0193-3973(88)90010-X]. Journal of Applied Developmental Psychology, 9(4), 421-440.

Sá, C. P. (1994). Sur les relations entre représentations sociales, pratiques socio-culturelles e comportement. Papers on Social Representations, 3(1), 40-46. 
Sears, R. R., Maccoby, E. E., \& Levin, H. (1957). Patterns of childrearing. Evanston, IL: Row, Peterson.

Selleri, P., \& Carugati, F. (in press). Taking care of children and pupils: Agreements and disagreements in parents' and teachers' social representations. In G. Marsico, K. Komatsu \& A. lannaccone (Eds.), Crossing boundaries: Intercontestual dynamics between family and school. Charlotte, NC: Information Age Publishing.

Sigel, I. E., McGillicuddy-De Lisi, A. V., \& Goodnow, J. J. (Eds.). (1992). Parental belief systems (2nd ed.). Hillsdale, NJ: Lawrence Erlbaum Associates.

Snellman, L., \& Raty, H. (1995). Conceptions of intelligence as social representations. European Journal of Psychology of Education, 3, 173-287.

Stanovich, P. J., \& Jordan, A. (1998). Canadian teachers' and principals' beliefs about inclusive education as predictors of effective teaching in heterogeneous classrooms. Elementary School Journal, 98(221-238).

Steinberg, L. (2001). We know some things: Parent-adolescent relationships in retrospect and prospect. Journal of Research on Adolescence, 11(1), 1-19.

Sternberg, R. J. (1985). Implicit theories of intelligence, creativity and wisdom. American Psychologist, 49(3), 607-627.

Sternberg, R. J. (2004). Culture and intelligence. American Psychologist, 59(5), 325-338.

Sternberg, R. J., Conway, B. E., Ketron, J. L., \& Bernstein, M. (1981). People's conceptions of intelligence. Journal of Personality and Social Psychology, 41, 37-55.

Stevens, J. (2002). Applied multivariate statistics for the social sciences (4th ed.). Mahwah, NJ: Lawrence Erlbaum Associates.

Ullman, J. B. (2001). Structural equation modeling. In B. Tabachnick \& L. Fidell (Eds.), Using multivariate statistics (4th ed., pp. 653- 771). Needham Heights, MA: Allyn \& Bacon.

Vala, J. (2002). Representações sociais e psicologia social do conhecimento quotidiano. In J. Vala \& M. B. Monteiro (Eds.), Psicologia Social (5th ed., pp. 457-502). Lisboa: Fundação Calouste Gulbenkian.

Valentim, J. P. (1997). Escola, igualdade e diferença. Porto: Campo das Letras.

Voelklein, C., \& Howarth, C. (2005). A review of controversies about social representations theory: A British debate. Culture and Psychology, 11(4), 431-454.

Wagner, W. (1993). Can representations explain social behaviour? A discussion of social representations as rational systems. Papers on Social Representations, 2, 236-249. 
